\title{
Physicochemical Characterization of Representative Firewood Species Used for Cooking in Some Colombian Regions
}

\author{
Hernán E. Díez and Juan F. Pérez \\ Grupo de Manejo Eficiente de la Energía (Gimel), Departamento de Ingeniería Mecánica, Facultad de Ingeniería, \\ Universidad de Antioquia (UdeA), Calle 70 No. 52-21, Medellín, Colombia \\ Correspondence should be addressed to Juan F. Pérez; juanpb@udea.edu.co
}

Received 5 January 2017; Revised 4 March 2017; Accepted 12 March 2017; Published 18 April 2017

Academic Editor: Sankar Chakma

Copyright (C) 2017 Hernán E. Díez and Juan F. Pérez. This is an open access article distributed under the Creative Commons Attribution License, which permits unrestricted use, distribution, and reproduction in any medium, provided the original work is properly cited.

\begin{abstract}
Socioeconomic conditions and the main firewood species used for cooking in three Colombian regions are studied in this work. The species collected were Cordia alliodora, Guazuma ulmifolia, Eucalyptus grandis, and Pinus patula. The used patterns of biomass and socioeconomic conditions of the selected regions were defined by means of secondary information. Firewood was physicochemically characterized and the species are compared with fossil fuels with regard to emissions of $\mathrm{CO}_{2}$, energy density, and costs. The studied regions require solutions to use firewood in eco-efficient systems, since in these rural regions people use biomass as an energy source. Studied firewood species are suitable to be gasified in fixed bed reactors due to their high volatile matter content $(>80 \%)$ and low ash content $(<1.8 \%)$. Pinus patula is the one with the highest fuel value index, mainly due to its low ash content $(0.4 \%)$. The firewood consumption in advanced stoves has environmental advantages resulting from its low $\mathrm{CO}_{2}$ emissions: a cubic meter of Eucalyptus could replace 113 liters of kerosene or $120 \mathrm{~m}^{3}$ of natural gas for cooking applications.
\end{abstract}

\section{Introduction}

Biomass consumption in developing countries has a fundamental role in satisfying the energy demand [1]. According to World Health Organization (WHO), about 3 billion people around the world use firewood, agriculture wastes, or coal for cooking and heating. Firewood consumption is associated with factors such as low income, traditions, availability $[2,3]$, and the pleasant taste of the food [4].

In Colombia between 1.3 and 1.6 million of households, mainly in rural areas, use firewood to cook in traditional stoves [5]. These stoves reach energy conversion efficiencies between $10 \%$ and $15 \%$ [6]. Low efficiency implies higher firewood consumption. Thereby, wood extraction as a fuel from native forests is one of the most responsible factors of deforestation [7]. Moreover, firewood burned in traditional cookstoves (three stones) reduces the indoor air quality, due to its high emissions of particulate matter $\left(\mathrm{PM}_{10}\right.$ and $\left.\mathrm{PM}_{2.5}\right)$, carbon monoxide $(\mathrm{CO})$, carbon dioxide $\left(\mathrm{CO}_{2}\right)$, and methane $\left(\mathrm{CH}_{4}\right)$. These emissions can generate respiratory diseases to people in contact with smoke, mainly women, children under five years, and old people [8]. WHO affirms that every year more than four million people die prematurely due to respiratory diseases caused by inhalation of pollutants from combustion in cookstoves [9]. The chronic obstructive pulmonary disease (COPD) is the fourth cause of death around the world and the biomass burned is one of the factors of high risk for the development of such disease [10].

In 2010, the World Bank estimated that the average annual cost of impacts on the health due to indoor air pollution in Colombia was about 357000 USD (COP/USD exchange rate on November 30,2016) [11]. Besides, the early deaths per year, mainly in rural regions that cook with firewood, were about 1150 [12]. The low population density in rural regions 9.7 inhabitants $/ \mathrm{km}^{2}$ [13] and Colombian geography make it difficult to change the use of low quality energy sources (e.g., firewood) to high quality energy ones such as natural gas or electricity. Therefore, to promote the use of firewood as a fuel to cook under eco-efficient criteria is a challenge. Since the last decade, top-lit-updraft (TLUD) cookstoves have been investigated. These advanced biomass cookstoves can help to solve problems of traditional cookstoves due to their higher 
thermal and combustion efficiencies that lead to decrease in the biomass consumption and to improve the indoor air quality $[14,15]$.

Despite social and environmental problems associated with the use of firewood, few works were found in the literature that characterize this renewable resource as a solid biofuel, looking for using the firewood in improved biomass cookstoves (TLUD cookstoves). In India, different authors have characterized native firewood species [3, 16]. Kataki and Konwer [16] studied four species of different families (Leguminosae, Myrtaceae, Sterculiaceae, and Verbenaceae). According to the extractive content, particle density, moisture content, and calorific value, they concluded that the firewood species of Leguminosae and Myrtaceae families have better properties as a fuelwood. Komala and Prasad [3] evaluated the firewood quality through surveys about the knowledge of population on native firewood species to cook, and the consumption patterns of firewood (i.e., low incomes, traditions, etc.). Cardoso et al. [17] evaluated 21 firewood species through interviews in three rural communities and estimated the fuel value index (FVI). The authors found a relation between the species with higher FVI and the most preferred ones by people. The FVI is defined as the product of heating value and density divided by the product of ash content (mass fraction) and moisture content (mass fraction) [7]. However, other models to estimate the FVI have been proposed in the literature $[18,19]$.

Naik et al. [20] characterized five types of biomass with potential for bioenergy using XRD, TGA, ICP-MS, CHNSO, FT-IR, and FT-NIR. The authors stated that species with lower heating value (16.7 and $15.7 \mathrm{MJ} / \mathrm{kg}$ ), higher temperature, and time of devolatilization (low reactivity) are not suitable as feedstock for energy. Molino et al. [21] collected different types of biomass from south of Italy with similar soil and same climatic conditions. This study stated that the ash composition of biomass depends on factors such as climate, growth site, and age of the plant. Moreover, the ash could be used as an amending soil. Popescu et al. [22] proposed an easy differentiation of various kinds of wood by FTIR spectroscopy, XRD, and TGA. The authors found differences between hardwood and softwood samples by means of the band intensities of FTIR spectra (in 1735 and $1510 \mathrm{~cm}^{-1}$ ) and found that the maximum temperature of devolatilization linearly decreases when wood density is higher.

Protásio et al. [23] compared the emissions of lignocellulosic wastes with fossil fuels. They concluded that it is possible to reduce the $\mathrm{CO}_{2}$ emissions if fossil fuels are substituted by neutral biomass and suggested to use the biomass in the same region where it is produced to avoid its transport.

This paper has the following objectives: (1) to socioeconomically characterize, through secondary information, regions that cook with firewood located at central, north, and south of Colombia; (2) to determine physicochemical properties of selected firewood species as solid biofuels for cooking applications; (3) to analyze the environmental impact by comparison with fossil fuels used for cooking and to estimate the economic savings for rural population when they replace fossil fuels such as natural gas, liquefied petroleum gas (LPG), or kerosene by firewood. The characterization of selected firewood species is a contribution to knowledge and help to design advanced cookstoves in future government programs [24].

\section{Methodology}

The socioeconomic conditions of the three Colombian regions that cook with firewood are specified and their relationships with the use of firewood are studied. The regions selected were Rionegro (Antioquia State); Sahagun and Cienaga de Oro (Cordoba State); and Sibundoy Valley (Putumayo State). Four firewood species used commonly for cooking in these regions were collected. The species were Cordia alliodora (Cordoba), Guazuma ulmifolia (Cordoba), Eucalyptus grandis (Antioquia), and Pinus patula (Putumayo).

Firewood consumption patterns and socioeconomic conditions of the selected regions were defined through secondary information from early studies conducted by governmental and nongovernmental agencies [25-27]. Firewood species were chemically characterized by ultimate and proximate analysis, thermogravimetric analysis (TGA), Fourier transform infrared (FTIR), and mineral composition of ash. The physical characterization includes the bulk and particle densities and hardness test (Shore D). Finally, firewood samples were compared with fossil fuels with regard to $\mathrm{CO}_{2}$ emissions; from an economical point of view, the economic savings by the use of firewood were calculated in comparison with fossil fuels commonly used for cooking in the studied regions.

2.1. Socioeconomic Information. According to Komala and Prasad [3], one of the most significant patterns of firewood consumption is low income; the income was evaluated by means of poverty estimation and unmet basic needs in the studied rural population. Besides, firewood consumption is associated with other socioeconomic aspects such as time spent for firewood collection, the average number of family members [28], and difficulties in having access to other "cleaner" energy resources (i.e., electricity, natural gas, and kerosene) [29]. The information for socioeconomic characterization was taken from databases and surveys carried out by the National Department of Statistics (DANE in Spanish) and information shared by Regional Autonomous Corporations (CAR in Spanish) [25-27].

2.2. Firewood Characterization. Regional autonomous corporations supplied the main firewood species used in the regions (logs with $\sim 15 \mathrm{~cm}$ of diameter and $\sim 70 \mathrm{~cm}$ of length). The samples were chipped at the same condition (i.e., the engine speed, aperture of teeth) in a Bandit 95XP chipper; the chips sizes were between 4 and $20 \mathrm{~mm}$. Then, these samples were dried at sunlight for one week; a fraction of the samples was milled and sieved trough sieve number 60 . Physicochemical characterization was carried out following the methodology shown below. 


\subsubsection{Chemical Characterization}

Proximate Analysis. Firewood samples were analyzed in a TGA Q50 instrument according to a modified ASTM standard D 5142 -04 [30], under an inert atmosphere using nitrogen gas at a flow rate of $100 \mathrm{~mL} / \mathrm{min}$. Samples were heated to $105^{\circ} \mathrm{C}$ at $10^{\circ} \mathrm{C} / \mathrm{min}$ for 15 minutes to determine moisture content. Samples were heated at $10^{\circ} \mathrm{C} / \mathrm{min}$ to $900^{\circ} \mathrm{C}$, isothermal state was fixed by $25 \mathrm{~min}$, and volatile material content was determined by mass loss between $105^{\circ} \mathrm{C}$ and $900^{\circ} \mathrm{C}$. Then, the internal temperature of the furnace was equilibrated at $715^{\circ} \mathrm{C}$. When the furnace reached $715^{\circ} \mathrm{C}$, the inert atmosphere was shifted to an oxidative atmosphere by purging $100 \mathrm{~mL} / \mathrm{min}$ of air for 20 minutes. The remaining mass after the isothermal state was considered as the ash content and the fixed carbon was determined by difference.

Ultimate Analysis. Firewood samples were analyzed in a CHNSO (LECO) Truspec micro according to ASTM D5373-08 method. CHN elemental content was determined at $1050^{\circ} \mathrm{C}$ in a helium atmosphere, and sulfur content was determined at $1350^{\circ} \mathrm{C}$ in a helium atmosphere. Neither the nitrogen $(\mathrm{N})$ nor the sulfur $(\mathrm{S})$ was detected by the CHNSO (LECO) equipment in most of the firewood samples. The oxygen concentration $(\mathrm{O})$ can be estimated by difference [23].

Ash Chemical Composition. The analysis of ash mineral content was carried out on a capillary electrophoresis system (EC) (Agilent Technologies 7100) for determining aluminum, calcium, magnesium, potassium, sodium, zinc, phosphor, and sulfur contents. Iron content was measured by means of atomic absorption (AA) on an atomic absorption spectrometer Sens AA, GBC scientific equipment. Iron, phosphor, and sulfur contents were determined according to SM 3111B, NTC 234, and AOAC 98002 methods, respectively.

Lower Heating Value. The higher heating value was determined in a calorimeter bomb (6100 Compensated Jacket Calorimeter) from Parr Instrument Company, using the standard ASTM E144-14. Tests were repeated three times. LHV was calculated based on HHV determinations using [31]

$$
\mathrm{LHV}_{\mathrm{db}}=\mathrm{HHV}_{\mathrm{db}}-2260 \times \mathrm{M}_{\mathrm{db}}-20300 \times \mathrm{H}_{\mathrm{db}}
$$

where $\mathrm{HHV}_{\mathrm{db}}(\mathrm{kJ} / \mathrm{kg})$ is the higher heating value on dry basis, $M_{d b}$ is the moisture content of the sample $(\mathrm{g} / \mathrm{g})$, and $\mathrm{H}_{\mathrm{db}}$ is the hydrogen content $(\mathrm{g} / \mathrm{g})$.

FTIR Spectroscopy. The FTIR spectroscopy for firewood samples was carried out in a Fourier transform infrared spectrophotometer IRAffinity-1 (Shimadzu). The aim of this test was to identify functional groups into firewood samples. FTIR spectroscopy has been used as a technique to gain insight into the chemical structure of wood and chemical changes in wood led by different factors (i.e., light irradiation, thermal treatments such as gasification/combustion, and microorganisms) [22].
Thermogravimetric Analysis. The thermogravimetric analysis (TGA) was conducted in a TG50 instrument. This test was carried out under constant nitrogen flow $(60 \mathrm{~mL} / \mathrm{min})$, from 25 to $600^{\circ} \mathrm{C}$ at a heating rate of $10^{\circ} \mathrm{C} / \mathrm{min}$. Close to $10 \mathrm{mg}$ of each sample was used, similar to the method used by Poletto [32]. This test is used to analyze the thermal stability of the firewood. From TGA, the biomass reactivity was estimated by means of (2), used by Barrera et al. [33], as follows:

$$
R=\frac{1}{W_{\text {in }}}\left(\frac{d w}{d t}\right)_{\text {max }},
$$

where reactivity $\left(R, \mathrm{~min}^{-1}\right)$ is equal to the inverse of initial weight $\left(W_{\text {in }}, \mathrm{mg}\right)$ in $\mathrm{mg}$ multiplied by the maximum rate of weight loss $(d w / d t)_{\max }$ in $\mathrm{mg} / \mathrm{min}$.

Fuel Value Index. The fuel value index (FVI) provides a quantification of firewood quality as a solid biofuel; this index has been used by different researchers for comparison purposes (i.e., firewood, scrubs, and charcoal). In the literature, there are different proposed models to estimate the FVI; that is, Kataki and Konwer [16] defined the FVI as the product of the calorific value and density divided by ash content; a similar model is used by Bhatt and Tomar [7]. In this study, FVI was defined as described by Cardoso et al. [17]; see

$$
\mathrm{FVI}=\frac{\mathrm{LHV}_{\mathrm{db}} \times \rho}{\mathrm{AC} \times \mathrm{MC}}
$$

where $\mathrm{LHV}_{\mathrm{db}}$ is the lower heating value on dry basis $(\mathrm{MJ} / \mathrm{kg})$, $\rho$ is the bulk density $\left[\mathrm{kg} / \mathrm{cm}^{3}\right], \mathrm{AC}$ is the ash content $(\mathrm{g} / \mathrm{g})$, and $\mathrm{MC}$ is the moisture content $(\mathrm{g} / \mathrm{g})$.

\subsubsection{Physical Properties}

Particle and Bulk Densities. The particle density was estimated according to Lenis and Pérez [34], following

$$
\rho_{p}=\frac{m_{p}}{V_{p}+V_{\mathrm{oil}}},
$$

where particle density $\left(\rho_{p}, \mathrm{~kg} / \mathrm{m}^{3}\right)$ is equal to particle mass $\left(m_{p}, \mathrm{~g}\right)$ divided by the sum of particle volume $\left(V_{p}, \mathrm{~cm}^{3}\right)$ and oil volume absorbed by the particle $\left(V_{\text {oil }}, \mathrm{cm}^{3}\right)$. The oil volume absorbed by the particle was estimated by means of density definition; see (5), where $m_{\text {oil }}(\mathrm{g})$ is the mass of oil retained by the firewood particle sample and $\rho_{\text {oil }}\left(\mathrm{kg} / \mathrm{m}^{3}\right)$ is the density of oil; this density should be known.

$$
V_{\mathrm{oil}}=\frac{m_{\mathrm{oil}}}{\rho_{\mathrm{oil}}} .
$$

The bulk density was determined according to the procedure presented in [34]. The test was replicated five times for each firewood sample.

Packing Factor and Sphericity. The packing factor is defined as the ratio between bulk density and particle density (see (6)). The sphericity is a measure of how spherical a particle is; 
TABLE 1: Properties of fossil fuels used for cooking.

\begin{tabular}{lcccc}
\hline Fuel & $\begin{array}{c}\mathrm{LHV} \\
(\mathrm{kJ} / \mathrm{kg})\end{array}$ & $\begin{array}{c}\text { Density } \\
\left(\mathrm{kg} / \mathrm{m}^{3}\right)\end{array}$ & $\begin{array}{c}E D_{\mathrm{ff}} \\
\left(\mathrm{MJ} / \mathrm{m}^{3}\right)\end{array}$ & $\begin{array}{c}\mathrm{EF} \\
(\mathrm{kg} \mathrm{CO} / \mathrm{L})\end{array}$ \\
\hline Natural gas $^{\mathrm{a}}$ & 50100 & 0.654 & 32.765 & 0.019 \\
Kerosene & $43095^{\mathrm{b}}$ & $810^{\mathrm{c}}$ & 34.907 & 2.5 \\
Liquefied petroleum gas $^{\mathrm{d}}$ & 49000 & 0.559 & 0.0274 & 1.656 \\
\hline
\end{tabular}

Adapted from ${ }^{\mathrm{a}}$ Protásio et al. [23], ${ }^{\mathrm{b}}$ Smoot et al. [74], ${ }^{\mathrm{c}}$ Elert [75], and ${ }^{\mathrm{d}}$ World Nuclear Association [76].

see (7) [35]. Both parameters could explain how the feedstock into a fixed bed is packed [34].

$$
\begin{aligned}
\mathrm{PF} & =\frac{\rho}{\rho_{p}}, \\
\psi & =\frac{\pi^{1 / 3}\left(6 V_{p}\right)^{2 / 3}}{S_{p}} .
\end{aligned}
$$

$V_{p}\left(\mathrm{~cm}^{3}\right)$ is the volume of the characteristic particle; it can be calculated by definition of particle density; see

$$
V_{p}=\frac{m_{c}}{\rho_{p}},
$$

where $m_{c}(\mathrm{~g})$ is the characteristic mass that is estimated by the Rosin-Rammler distribution and $\rho_{p}\left(\mathrm{~kg} / \mathrm{m}^{3}\right)$ is the particle density. Lenis and Pérez [34] assumed that a wood chip is a parallelepiped where the volume is a function of sides longitudes, $V_{p}\left(d_{1}, d_{2}, d_{3}\right)$. Then, $d_{1}$ is the characteristic longitude $(\lambda)$ estimated by means of Rosin-Rammler distribution [36], $d_{2}$ is the thickness of the particle that was statistically obtained, and $d_{3}$ is the width of the particle that can be calculated using (9). Thus, the lengths of particles are completely determined.

$$
d_{3}=\frac{V_{p}}{\lambda \times d_{2}} .
$$

Hardness of Firewood. The shore D hardness of firewood samples was measured using a hardness tester with shore D scale (Ceast). The shore D hardness of wood biomass has been determined by other authors [37, 38]. The hardness test was replicated five times, and the hardness test was conducted according to the procedure proposed by ASTM D2240-00 standard [39].

2.3. Comparison of Equivalent $\mathrm{CO}_{2}$ Emissions between Firewood and Fossil Fuels. The traditional fossil fuels used for cooking in Colombia are kerosene, natural gas, and LPG [40]. Protásio et al. [23] propose a comparison between $\mathrm{CO}_{2}$ emissions of fossil fuels and biomass; their method supposes complete combustion; see

$$
\mathrm{CO}_{2, \text { ret }}=\mathrm{Eq} V_{\mathrm{ff}} \times \mathrm{EF}
$$

where $\mathrm{CO}_{2}$,ret is $\mathrm{CO}_{2}$ mass $(\mathrm{kg})$ prevented if a specific fossil fuel is replaced by a specific firewood species. $\operatorname{Eq} V_{\mathrm{ff}}\left(\mathrm{m}^{3}\right)$ is the volume of fossil fuel equivalent to a cubic meter of biomass for energy production. $\mathrm{EF}(\mathrm{kg} \mathrm{CO} / \mathrm{L})$ is the emission factor of each fossil fuel and it is presented in Table 1. The emission factor of firewood is considered to be zero because a portion of $\mathrm{CO}_{2}$ retained by the tree, during its growth, is returned to the environment through thermochemical conversion of biomass (i.e., combustion, gasification, or pyrolysis) [23].

$\mathrm{Eq} V_{\mathrm{ff}}$ is calculated for $1 \mathrm{~m}^{3}$ of firewood. It indicates the volume of fossil fuel that could be replaced by $1 \mathrm{~m}^{3}$ of firewood; this parameter was estimated using

$$
\mathrm{Eq} V_{\mathrm{ff}}=\frac{E_{\text {biomass }}}{E D_{\mathrm{ff}}},
$$

where $E_{\text {biomass }}[\mathrm{kJ}]$ is the energy liberated by $1 \mathrm{~m}^{3}$ of firewood and $E D_{\mathrm{ff}}\left(\mathrm{kJ} / \mathrm{m}^{3}\right)$ is the energy density that is the product between LHV $(\mathrm{kJ} / \mathrm{kg})$ and the density of fossil fuel $\left(\mathrm{kg} / \mathrm{m}^{3}\right)$. The cost of energy to cook is calculated according to energy conversion efficiency of natural gas, LPG, kerosene, and firewood cookstoves according to the method proposed by Çengel and Boles [41]. The conversion efficiencies used for estimating the cost of useful energy were $38 \%, 56 \%, 43 \%$, and $30 \%$ for gas natural, LPG, kerosene, and firewood cookstoves, respectively [42-44].

\section{Results and Discussion}

3.1. Some Representative Colombian Regions That Cook with Firewood. Figure 1 shows in gray, the states selected in this work (eastern of Antioquia, Cordoba, and north of Putumayo). Firewood species were taken from Sibundoy (Putumayo state), Rionegro (Antioquia State), and Cienaga de Oro and Sahagun (Cordoba State), with rural areas of 93, 196, 751 , and $976.6 \mathrm{~km}^{2}$, respectively. According to municipal government programs 2012-2015, these regions have 3895, 40651, 33338 , and 42330 inhabitants in rural zones, respectively. The socioeconomic conditions for Antioquia, Cordoba, and Putumayo are shown in Table 2. According to DANE, in Colombia, rural population spend 1:30 (hh:mm) average to collect firewood and to carry out different housework (i.e., the collection of water). Aristizabal et al. [28] report that firewood consumption in rural zones is approximately $6.09 \mathrm{~kg} /$ day per capita.

According to Table 2, in the Caribbean region (Cordoba state) near half of rural population use firewood, due to its higher poverty percent and unmet basic needs; these two parameters have a relationship with low income. In the literature, Komala and Prasad [3] report that low income is one 
TABLE 2: Socioeconomic conditions of Cordoba, Antioquia, and Putumayo states in rural zones: people in a household, poverty, and percentage of firewood consumption.

\begin{tabular}{lccc}
\hline Socioeconomic conditions & \multicolumn{2}{c}{ States } \\
Antioquia & Cordoba & 3.4 & 3.4 \\
\hline Average of people in a household & 4.1 & 29.4 & 44.3 \\
Estimation of poverty (\%) & 51 & 47.5 & 46.2 \\
Unmet basic needs (\%) & 76.6 & 38 & 34 \\
Firewood consumption (\% of population) & 48 & 48 \\
\hline
\end{tabular}

Comments: information adapted from Quality Life Survey (EVC in Spanish) 2013 carried out by DANE in rural zones of Colombia [25].

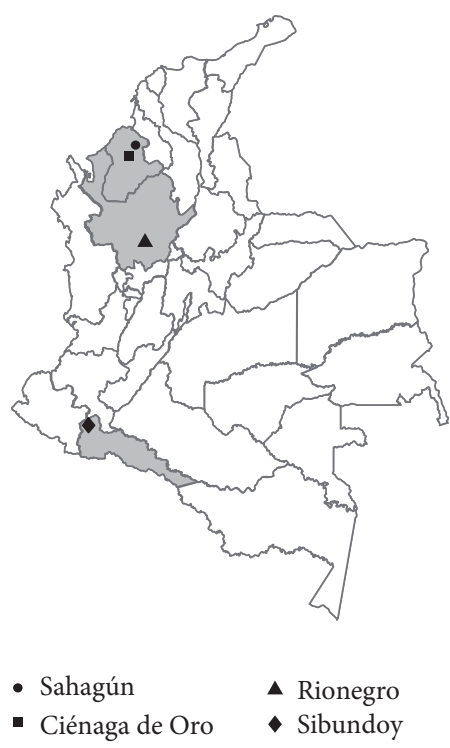

FIGURE 1: Colombian regions studied.

of main reasons for firewood consumption. In the Amazonia case (Putumayo state), the $34 \%$ of the rural population use firewood as a fuel due to the fact that natural gas is not supplied to the households of south of Colombia; then its inhabitants should use another energy source to satisfy their cooking needs. In Antioquia, the $38 \%$ of the rural population consume firewood for cooking and east of Antioquia is the region with the highest firewood consumption of the state [28].

3.1.1. Forestry of Selected Firewood Species. Firewood species selected were Pino patula (Pat) from Sibundoy Valley in Putumayo, Eucalyptus grandis (Euc) from eastern of Antioquia, Guazuma ulmifolia (Gua), and Cordia alliodora (Nog) from Sahagun and Cienaga de Oro (Cordoba state). The species have been selected in function of the biomass used for cooking in the regions under study. Eucalyptus species have been proposed by projects of improved cookstoves in Antioquia as an energy source for cooking [26], and Pinus patula, Guazuma ulmifolia, and Cordia alliodora have been recognized as firewood resources by the rural population of studied regions [25]. Moreover, in this work, silvicultural variables to ensure the availability of firewood species to the biomass supply chain for households are considered. The main forest parameters are tree density (tree/ha), mean annual increment (MAI, $\mathrm{m}^{3} / \mathrm{ha} /$ year), and harvest time (years). Table 3 shows that all firewood species have fast growth and availability in rural regions. The harvest time presents significant differences between species, where Gua has the lowest harvest time (4 years) and Nog has the highest one (20 years). Gua and Nog have low tree density since these species are used for forest-pasture systems in Cordoba [45], and Pat and Euc have been used for reforestation in some regions in Colombia [46]. This explains the higher tree density of these two species.

3.2. Physicochemical Properties of Firewood. The proximate and ultimate analysis results are shown in Table 4 . The carbon content of Euc is significantly higher than other three samples, and the hydrogen content is between 5.8 and $6.2 \%$ for all samples. Pat presents the highest oxygen content (46.3\%); all firewood presents a low nitrogen content less than $0.3 \%$. These results are in agreement with Mosiori et al. [47] that report carbon content in ranges from 42 to $54 \%$. Moreover, they suggest that the nitrogen content should be less than $0.6 \%$ to use biomass as a feedstock for energy purposes. Thus, all firewood species studied are suitable for gasification [47]. The hydrogen content for wood is about $6 \%$ and the oxygen content of the biomass is between 40 and $51 \%$ [47]. The results of ultimate analysis also agree with values for $\mathrm{C}, \mathrm{H}$, and $\mathrm{O}$ content for wood chips found by Tortosa Masiá et al. [48] and García et al. [49]. The sulfur content was not detected in the firewood samples studied in this work. The difference between ash compositions of four firewood species is due to several factors such as climate, soil, growth, and age of each species [21]. These parameters were not controlled in this work.

In Table 4, it can be seen that the moisture content of all firewood samples is near $10 \%$. This indicates that these firewood species are suitable feedstock for gasification process, where the maximum moisture content is around $25 \%$ wt [50]. All firewood samples have a higher volatile matter content (>80\% wt.), which leads to decrease in the ignition temperature of firewood samples [51], which makes the firewood more reactive for the thermochemical process. All firewood samples have low ash content ( $<2 \%$ wt.), where high volatile matter content and low ash content are considered good properties of the biomass for gasification [21, 52]. The main difference between four species is the ash content; for example, Pinus patula minimizes the possibilities of ash deposition on the gasifier, due to its lower ash content $(0.4 \%)$ [53]. 
TABLE 3: Silvicultural parameters of firewood species selected.

\begin{tabular}{lcccc}
\hline Silvicultural parameters & Guazuma ulmifolia (Gua) & Cordia alliodora (Nog) & Eucalyptus grandis (Euc) & Pinus patula (Pat) \\
\hline MAI (m $\mathrm{m}^{3} /$ ha/year) & 9.5 & $8-20$ & $16-25$ & 20 \\
Tree density (tree/ha) & 39 & 100 & 278 & $278-625$ \\
Harvest time (years) & 4 & 20 & 8 & 13 \\
\hline
\end{tabular}

Comments: information adapted from Silvicultural guides (Cenicafé) [45, 46].

TABle 4: Physicochemical properties of firewood species ( \pm standard deviation).

\begin{tabular}{|c|c|c|c|c|}
\hline & \multicolumn{4}{|c|}{ Firewood species } \\
\hline & Gua & Nog & Euc & Pat \\
\hline \multicolumn{5}{|l|}{ Ultimate analysis $(\% \mathrm{wt} .)^{\mathrm{a}}$} \\
\hline $\mathrm{C}$ & $49.1(0.7)$ & $49.2(0.2)$ & $51.0(0.2)$ & $47.2(0.6)$ \\
\hline $\mathrm{H}$ & $5.8(0.2)$ & $5.8(0.1)$ & $6.1(0.1)$ & $6.2(0.1)$ \\
\hline $\mathrm{N}$ & ND & ND & ND & $0.3(0.01)$ \\
\hline $\mathrm{O}^{\mathrm{b}}$ & $45.1(0.5)$ & $45.0(0.1)$ & $42.9(0.3)$ & $46.3(0.4)$ \\
\hline \multicolumn{5}{|c|}{ Proximate analysis $(\% \mathrm{wt} .)^{\mathrm{c}}$} \\
\hline Volatile matter & 80.92 & 81.75 & 81.66 & 84.11 \\
\hline Fixed carbon & 17.28 & 16.72 & 17.17 & 15.49 \\
\hline Ash & 1.80 & 1.53 & 1.17 & 0.40 \\
\hline Moisture (\% wt.) & 7.99 & 7.41 & 10.28 & 8.55 \\
\hline \multicolumn{5}{|l|}{ Physical properties } \\
\hline Bulk density $\left(\mathrm{kg} / \mathrm{m}^{3}\right)$ & $138.26(1.70)$ & $169.70(2.50)$ & $221.83(4.11)$ & $196.42(3.66)$ \\
\hline Particle density $\left(\mathrm{kg} / \mathrm{m}^{3}\right)$ & $381(71)$ & $404(42)$ & $734(36)$ & $670(56)$ \\
\hline Packing factor $(-)$ & $0.363(0.072)$ & $0.420(0.050)$ & $0.303(0.020)$ & $0.293(0.030)$ \\
\hline Sphericity (-) & 0.70 & 0.63 & 0.62 & 0.72 \\
\hline Hardness shore D $(-)$ & $45.8(1.3)$ & $50.0(2.0)$ & $59.4(0.9)$ & $49.0(1.2)$ \\
\hline \multicolumn{5}{|l|}{ Energy property } \\
\hline $\mathrm{LHV}_{\mathrm{db}}(\mathrm{kJ} / \mathrm{kg})$ & $16819(91)$ & $18157(38)$ & $17795(90)$ & $17646(143)$ \\
\hline
\end{tabular}

For the physical properties shown in Table 4, Euc and Pat have higher particle and bulk densities than Gua and Nog. However, the packing factor (Euc: 0.303 and Pat: 0.293 ) is lower than Gua (0.363) and Nog (0.420). A higher packing factor could lead to a better accommodation in the bed [37], where Gua and Nog could be better packed into the gasifier. These results agree with the data presented by Lenis and Pérez [34], where the sphericity and packing factor for wood chips were 0.76 and 0.38 , respectively.

Higher particle sphericity was obtained for Pat and Gua. Hence, according to Lenis et al. [54], a biomass with higher sphericity leads to a better accommodation of particles into the bed. However, the random packing of biomass inside the reactor is mainly favored by bulk and particle densities [54]. Thereby, if the packing factor increases, the temperature of reaction in fixed bed gasification increases due to the lower radiation penetration in the solid biomass because there is a higher amount of solid fuel in the reaction process [54]. The higher reaction temperature favors the formation of hydrogen and carbon monoxide in the producer gas [55].

The Van Krevelen diagram allows comparing firewood with solid fossil fuels [56] and shows the position of the biomass in front of other fuels in terms of $\mathrm{C}, \mathrm{H}$, and

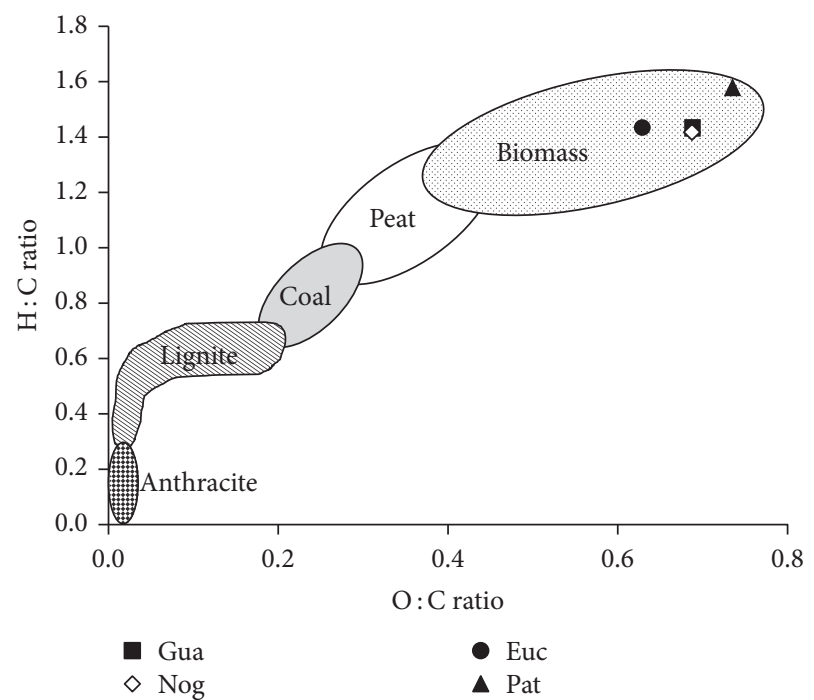

Figure 2: Van Krevelen diagram.

O contents [57]. The position of biomass (solid fuel with lower heating value) is due to the lower content of $\mathrm{C}$ and higher contents of $\mathrm{H}$ and $\mathrm{O}$; see Figure 2. Firewood with higher 


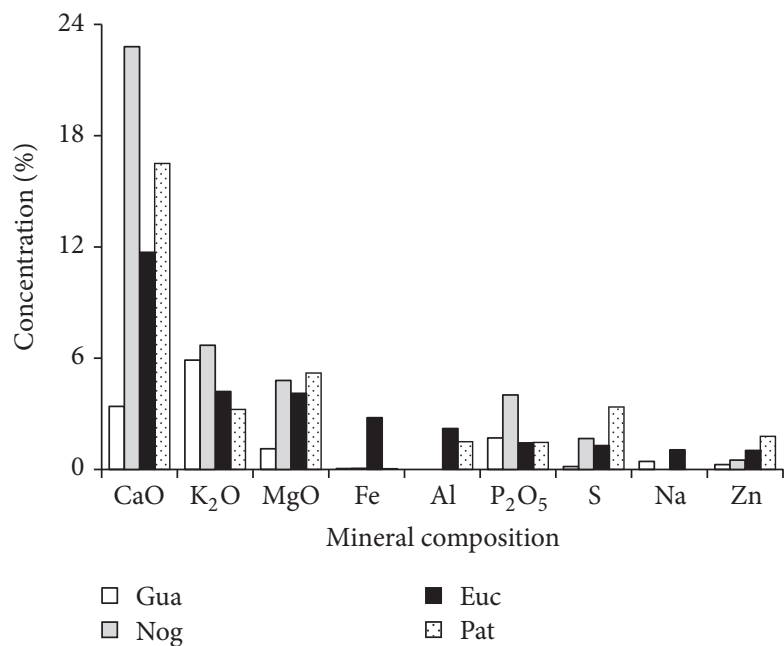

Figure 3: Ash chemical composition of firewood.

$\mathrm{H}$ and $\mathrm{C}$ contents is favorable for its energy properties, but higher content of $\mathrm{O}$ is not desirable because the heating value of biomass decreases [23]. According to $\mathrm{O}: \mathrm{C}$ ratio and fixed carbon content, the Pat has the highest $\mathrm{O}: \mathrm{C}$ ratio $(0.736)$ and the lowest fixed carbon content (15.49\%). Therefore, this composition explains the lower heating value of Pat with regard to other species (Euc and Nog). However, Pat has higher $\mathrm{H}$ : C ratio (1.576) than Gua (1.429); this leads Pat to reach higher LHV than Gua. This is in agreement with Tanger et al. [58], who concluded that the biomass is suitable as a fuel for thermochemical processes when $\mathrm{H}: \mathrm{C}$ ratio is higher and $\mathrm{O}: \mathrm{C}$ ratio is lower.

Ash Chemical Composition. According to Figure 3, Gua and Nog samples presented a higher $\mathrm{K}$ content than Pat and Euc. All firewood samples have low Na content. The presence of $\mathrm{Na}$ and $\mathrm{K}$ in ash of firewood could favor melting problems such as deposition on the gasifier grate and bed agglomeration [53]; the $\mathrm{Na}$ and $\mathrm{K}$ in ash could favor low melting temperature eutectics [59]. However, the presence of $\mathrm{Ca}$ could be responsible for higher melting temperatures. The main ash component in the ash of firewood was $\mathrm{Ca}$ (except for $\mathrm{Gua}$ ). So, firewood with higher content of $\mathrm{Ca}$ in ash could be suitable for gasification due to the lower potential associated with ash related problems [53].

On the other hand, the ash has applications as an amending soil, and it can be used as an additive for prefabricated concrete structural products [60]. In rural household scale, ash is an important reserve of soil nutrients; it suggests its applications for amending soil due to its high mineral content of Ca and K [61]. Therefore, ash from Nog, Euc, and Pat could be a suitable gasification byproduct to amend soils.

Energy Parameters of Firewood Species. Eucalyptus presents the highest energy density, mainly due to its high bulk density $\left(221.83 \mathrm{~kg} / \mathrm{m}^{3}\right)$, but Pat has the higher FVI due to its low ash content $(0.41 \%)$, which shows that pine cropped on the south of Colombia has higher potential as a fuel for cooking process (see Figure 4). The firewood ( Nog and Gua) from

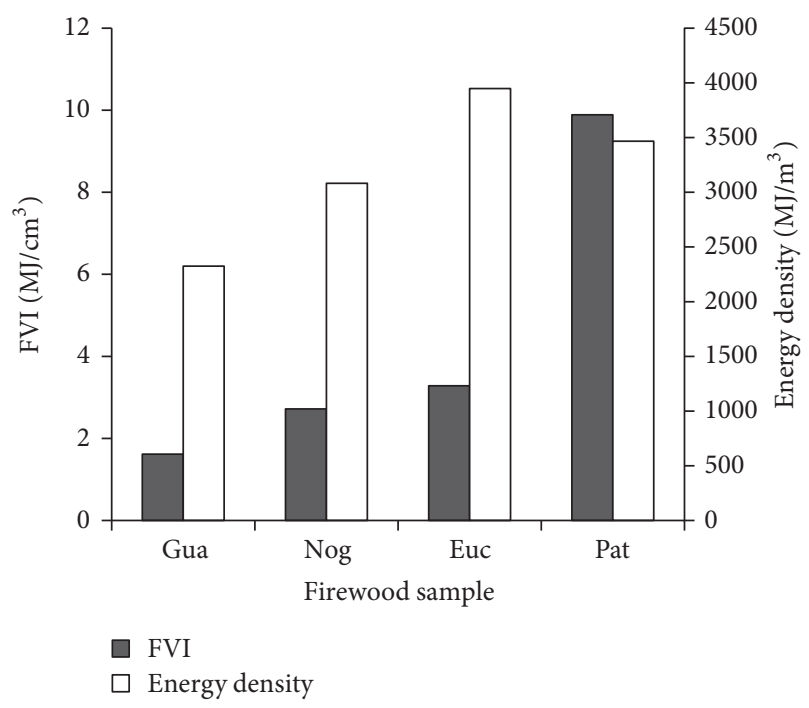

Figure 4: Fuel value index (FVI) and energetic density.

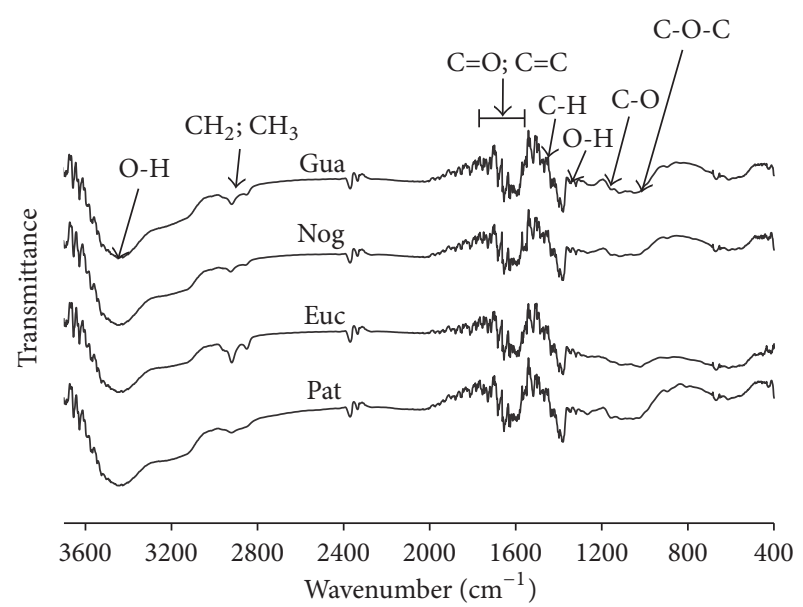

FIGURE 5: FTIR spectra of firewood species overlapped.

Cordoba State presented low energy density and FVI due to their highest ash content and lowest bulk density.

Cardoso et al. [17] report that people usually prefer firewood species with the highest FVI values for cooking and heating processes. The energy density value is an important property for solid fuels since it represents the interaction between heating value and density of biomass [23]. Brenes [62] stated that high ash content and low density are the main variables that adversely affect the FVI. Protásio et al. [23] reported similar values for energy densities for eucalyptus and pinus $\left(\sim 3600 \mathrm{MJ} / \mathrm{m}^{3}\right)$.

FTIR Spectrum. Figure 5 shows that the chemical structure of the four studied firewood species is similar; spectrograms do not show significant differences. This can be corroborated with the ultimate and proximate analysis where the differences are close. The band between 3400 and $3450 \mathrm{~cm}^{-1}$ is associated with $\mathrm{O}-\mathrm{H}$ vibrations in hydroxyl groups [63]. Moisture content could take part in the formation of hydrogen bonds [63]. O-H stretching band presents similar shape 


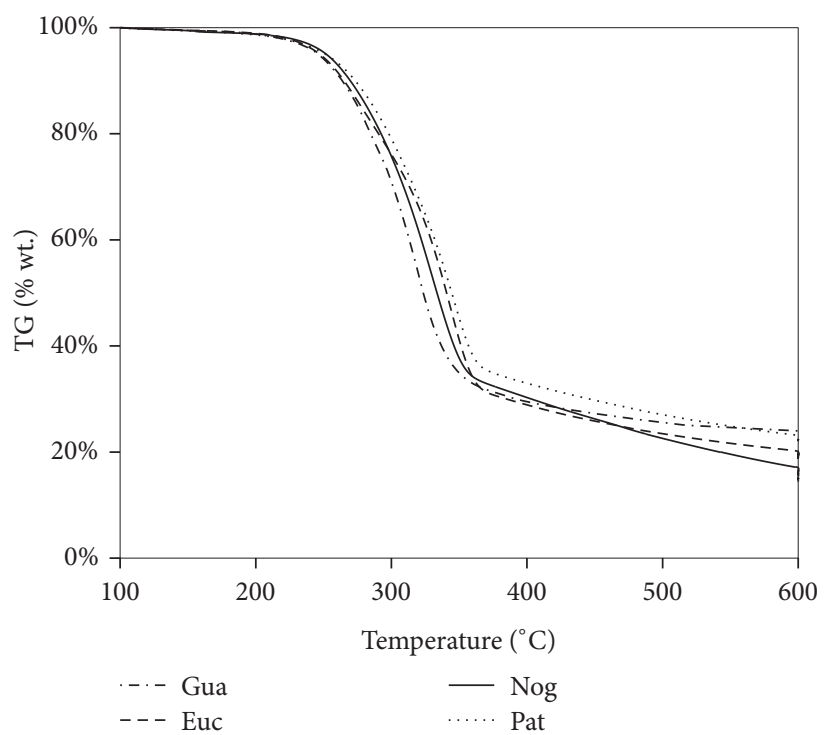

(a)

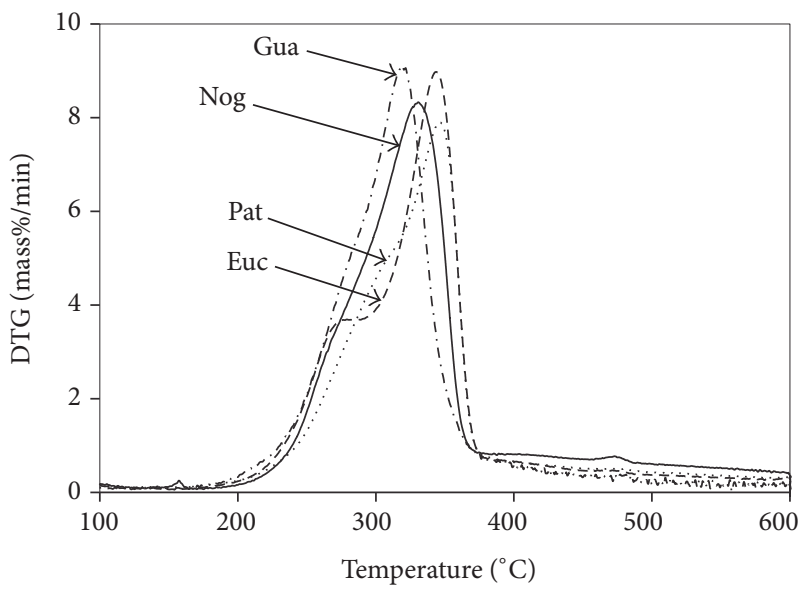

(b)

Figure 6: (a) DTG and (b) TG curves.

and intensity, which agrees with the ultimate and proximate analysis of firewood samples where moisture, hydrogen, and oxygen contents vary between (7.99 and 10.28)\%, (5.8 and $6.2) \%$, and (42.9 and 46.3$) \%$, respectively.

In Figure 5, the peak at $1230 \mathrm{~cm}^{-1}$ represents the $\mathrm{C}-\mathrm{O}$ $\mathrm{C}$ stretching in phenol-ether bonds of lignin; the peak at $1160 \mathrm{~cm}^{-1}$ corresponds to $\mathrm{C}-\mathrm{O}-\mathrm{C}$ stretching in pyranose rings and $\mathrm{C}=\mathrm{O}$ stretching in aliphatic groups [64]. The peak at $1330 \mathrm{~cm}^{-1}$ is assigned to $\mathrm{C}-\mathrm{H}$ vibration in holocellulose and $1228 \mathrm{~cm}^{-1}$ for guaiacyl ring. The peak at $1738 \mathrm{~cm}^{-1}$ is assigned to unconjugated $\mathrm{C}=\mathrm{O}$ in hemicellulose [65]. The peak at $1505 \mathrm{~cm}^{-1}$ corresponds to aromatic $\mathrm{C}=\mathrm{C}$ bond stretching in lignin [65]. These functional groups can be a support to analyze the changes in firewood after gasification and to evaluate and characterize the biochar properties [66].

Thermogravimetric Analysis. Figure 6(a) shows that four firewood species have similar thermal stability; this is in agreement with the proximate analysis, where the amount of volatile matter is close. However, DTG curve (Figure 6(b)) shows small differences in the composition. For Euc and Pat, a visible shoulder between 250 and $300^{\circ} \mathrm{C}$ is attributed to hemicellulose decomposition [67-69]. Gua and Nog present hemicellulose shoulders less evident and reach the maximum peak at lower temperature $\left(324\right.$ and $334^{\circ} \mathrm{C}$, resp.) than Pat and Euc (both near to $345^{\circ} \mathrm{C}$ ). This maximum peak refers to cellulose degradation. This is in agreement with results obtained by Grønli et al. [70]; hardwoods show a more delayed shoulder than softwood and the degradation of hardwoods take place within a narrower range of temperature than softwood. The lignin starts to decompose between 200 and $600^{\circ} \mathrm{C}$; its decomposing rate is lower than cellulose and hemicellulose [68]; therefore, it is difficult to identify the lignin degradation due to its wide range.
According to Figure 6(b), there are differences between decomposition of four firewood species, where Gua and Nog take less time in decomposition. Moreover, Figure 6(a) shows that the higher char yield was reached for Gua with $22.2 \%$, followed by Pat (20.7\%), Euc (18.4\%), and, finally, $\operatorname{Nog}(16.0 \%)$; this char is the residue from TGA analysis at $600^{\circ} \mathrm{C}$. Analyzing the fixed carbon in all firewood species, a relation between fixed carbon and biochar yield from TGA is highlighted, except for Pat. Therefore, for biomass gasification in TLUD reactors, it is expected that biochar yield increases with a higher fixed carbon content in biomass.

Reactivity. The initial temperature of devolatilization for each firewood sample is similar; there is a slight difference between Gua and Pat, where the difference in initial temperature is around $12^{\circ} \mathrm{C}$. This similar behavior is in agreement with proximate and ultimate analysis, where volatile matter : fixed carbon ratio ( $\mathrm{MV}$ : $\mathrm{CF}$ ratio) and $\mathrm{H}: \mathrm{C}$ ratio are very close. Moreover, there are other effects on devolatilization stage such as the structures of firewood [71], which may be attributed to the strength among cellulose, hemicellulose, and lignin in different firewood species [72]. According to thermal derivative criteria, Figure 7 shows that when reactivity of firewood increases, the initial temperature of devolatilization decreases. Then, Gua has the highest rate of decomposition (0.092 $\left.\mathrm{min}^{-1}\right)$, followed by $\operatorname{Euc}\left(0.090 \mathrm{~min}^{-1}\right)$, Nog $\left(0.083 \mathrm{~min}^{-1}\right)$, and Pat $\left(0.079 \mathrm{~min}^{-1}\right)$. Thus, according to thermal criteria, Gua has the lowest initial temperature of devolatilization $\left(230^{\circ} \mathrm{C}\right)$ and Pat has the highest one $\left(\sim 242^{\circ} \mathrm{C}\right)$.

3.3. Comparison of Firewood Species with Fossil Fuels Used for Cooking. The firewood is compared with liquid fossil fuel (kerosene). It was found that $1 \mathrm{~m}^{3}$ of firewood could replace between 67 and 113 liters of kerosene that represent 


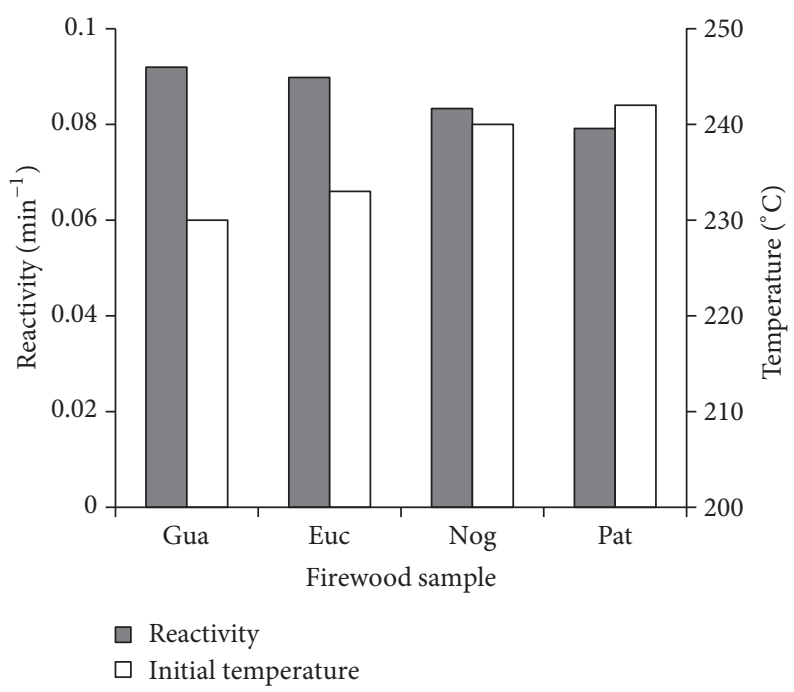

Figure 7: Relative reactivity and initial temperature of devolatilization.

between 111 and $187 \mathrm{~kg}$ of $\mathrm{CO}_{2}$. According to Figure 8(b), the firewood consumption could represent economic savings, since if natural gas, LPG, or kerosene is replaced by firewood, economic savings could be $6.9,8.1$, and 5.9 times, respectively. The cost of LPG is the highest because this fuel is supplied in gas cylinders between 20 and 30 lbs, whereas the natural gas is usually supplied to households through a pipeline. The Gua could replace a lower amount of fossil fuel since this species has low LHV, FVI, and energy density, due to the fact that Gua has the highest ash content and the lowest bulk density. The results for replacement fossil fuels by firewood are in agreement with Protásio et al. [23], who reported that Eucalyptus and Pinus could replace 116.7 and $104 \mathrm{~m}^{3}$ of natural gas, respectively.

If the firewood for cooking is used in the same place, this avoids the $\mathrm{CO}_{2}$ emissions from fossil fuels since the biomass is not transported over long distances [23]. Under this hypothesis, it is possible to consider the biomass as fuel with zero $\mathrm{CO}_{2}$ emissions [23]. Firewood does not need to use fossil fuel for its production because it can be taken from fallen branches [73]. Then, $1 \mathrm{~m}^{3}$ of biomass could retain until $2300 \mathrm{~kg}$ of $\mathrm{CO}_{2}$. The highest $\mathrm{CO}_{2}$ retention could be obtained from Euc and the lowest from Gua $\left(1300 \mathrm{~kg}\right.$ of $\left.\mathrm{CO}_{2}\right)$; see Figure 8(c). According to Figure 8(a), $1 \mathrm{~m}^{3}$ Euc could replace the highest amount of natural gas, followed by Pat. Both firewood species have great potential as energy sources for cooking in Colombian rural areas.

\section{Conclusions}

The regions studied require solutions for using firewood in clean systems for cooking. The efforts should be aimed at helping the rural population, in which people use the biomass as an energy source due to facts such as the low cost of firewood, low income, and traditions. Firewood is one of their main fuels.

Some representative firewood species (Gua, Nog, Euc, and Pat) used in some regions of Colombia for cooking were physicochemically characterized. In general, the types of firewood considered in this study have similar chemical compositions (FTIR, ultimate and proximate analysis), which can be corroborated by the thermogravimetric analysis that shows a similar thermal stability. However, there are slight differences in devolatilization rate and initial temperature, where Gua tends to react at a low temperature $\left(230^{\circ} \mathrm{C}\right)$, whereas Pat tends to react at $242^{\circ} \mathrm{C}$. The results found in this work show that all firewood species are suitable for gasification process due their high volatile matter content $(>80 \%)$ and low ash content $(<1.8 \%)$. Pat could be suitable as an energy source for cooking due to its highest FVI $\left(9.8 \mathrm{MJ} / \mathrm{cm}^{3}\right)$, mainly for its low ash content $(0.4 \%)$.

According to the physical characterization of firewood, the highest bulk density of Euc $\left(221.83 \mathrm{~m}^{3} / \mathrm{kg}\right)$ and Pat $\left(196.42 \mathrm{~m}^{3} / \mathrm{kg}\right)$ leads to a higher energy density, which is favorable for the production of energy in thermochemical processes, that is, gasification. But, Euc and Pat woodchips have a lower packing factor (0.303 and 0.293); it implies a worse accommodation into the bed than Nog (0.420). A high packing factor favors the gasification process.

The firewood consumption in advanced stoves has environmental advantages in comparison to fossil fuels. A cubic meter of eucalyptus could replace 113 liters of kerosene or $120 \mathrm{~m}^{3}$ of natural gas for energy application (i.e., cooking). Thus, the eucalyptus could avoid producing between 248 and $2315 \mathrm{~kg}$ of $\mathrm{CO}_{2}$ in function of the fossil fuel replaced and costs associated with the firewood consumption could be 6 times lower than fossil fuels such as natural gas, LPG, and kerosene. 


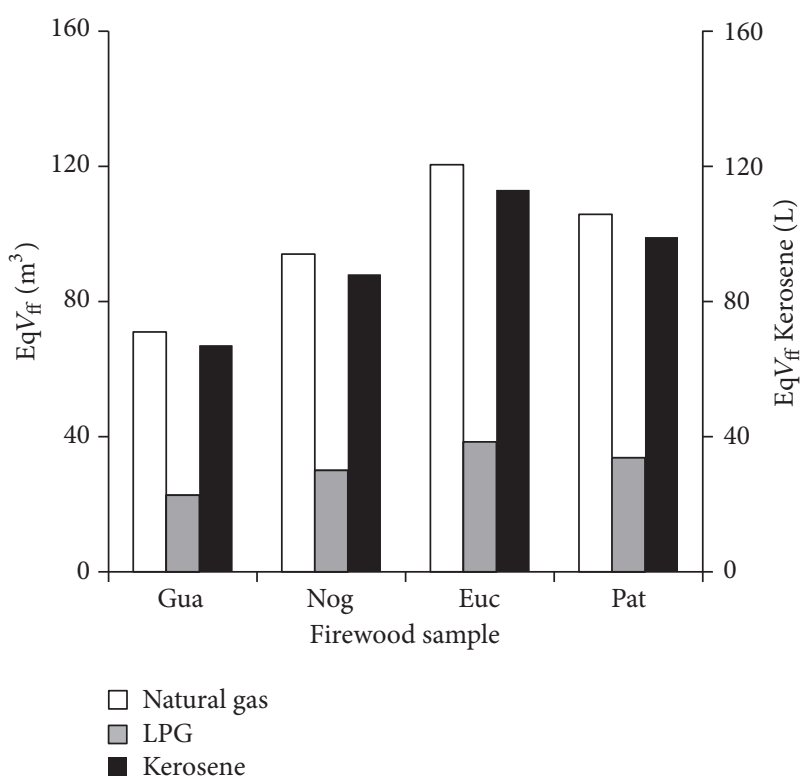

(a) Volume equivalent of fossil fuel by $1 \mathrm{~m}^{3}$ of biomass

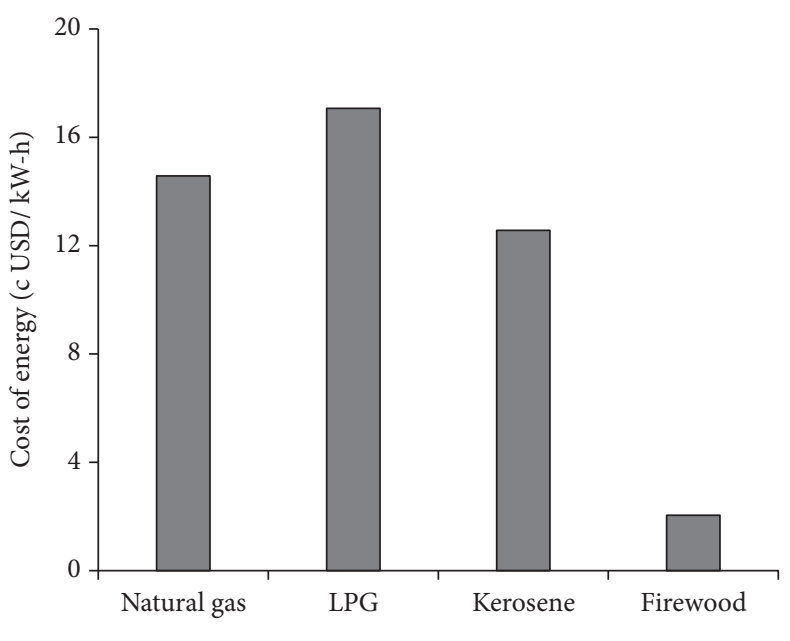

(b) Cost of useful energy for cooking

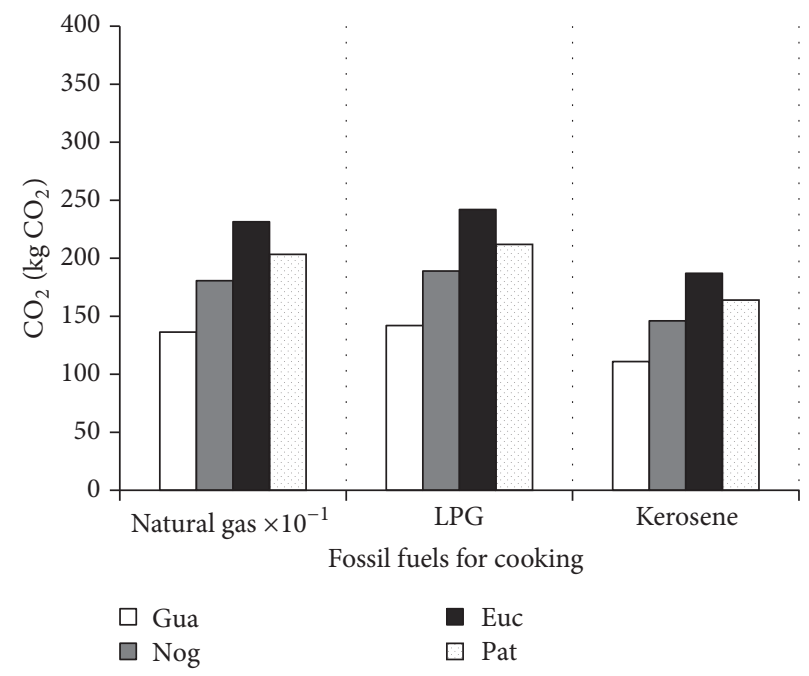

(c) $\mathrm{CO}_{2}$ retained by $1 \mathrm{~m}^{3}$ of biomass

FIGURE 8: Comparison of volume equivalent, emissions, and costs between firewood species and fossil fuels used for cooking in Colombia.

The characterization of firewood as fuel for cooking is the starting point for further research focused on improved cookstoves (i.e., TLUD cookstoves) and to evaluate the effect of feedstock on the biochar properties. Moreover, the biochar can be characterized to define potential applications in a rural household context.

\section{Conflicts of Interest}

The authors declare that there are no conflicts of interest regarding the publication of this paper.

\section{Acknowledgments}

The authors acknowledge the financial support of CODIUniversidad de Antioquia through the research project
"Integration Strategies of Wood Planted in Colombia under Thermochemical Bio-Refinery Concepts: Thermodynamic Analysis and Characterization of Bioproducts (in Spanish), PRG2014-1016" and the support of the same institution (UDEA) through the project "Sostenibilidad 2016-2017."

\section{References}

[1] J. F. Ramírez Quirama and A. L. Taborda Vergara, “Consumo de leña en fogones tradicionales en familias campesinas del oriente antioqueño," Producción + Limpia, vol. 9, no. 1, pp. 99-114, 2014.

[2] K. J. Wessels, B. F. N. Erasmus, M. Colgan et al., "Impacts of communal fuelwood extraction on LiDAR-estimated biomass patterns of savanna woodlands," in Proceedings of the 32nd IEEE International Geoscience and Remote Sensing Symposium (IGARSS '12), pp. 1676-1679, IEEE, Munich, Germany, July 2012. 
[3] H. P. Komala and A. G. D. Prasad, "Utilization pattern of biomass energy and socioeconomic dimensions associated with Yelandur, Karnataka, India," International Journal of Energy and Environmental Engineering, vol. 5, no. 2-3, pp. 1-7, 2014.

[4] F. Mejía, "Implicaciones Ambientales Del Uso De Leña Como Combustible Doméstico En La Zona Rural De Usme," 2011, http://www.bdigital.unal.edu.co/4125/1/905057.2011.pdf.

[5] L. Cardenas, J. Aristizabal, and R. Gomez, "Estufas eficientes de leña: Una parte de la solución a los problemas de la cocción doméstica en el medio rural colombiano," Fundación Natura, Bogotá, Colombia, 2014, http://www.natura.org.co.

[6] P. S. Anoopa, D. Scaria, N. S. Nithya, and M. Prahitha, Energy Consumption Benchmark Studies on Parboiled Rice Cooking in Kerala, Energy Management Centre, 2005.

[7] B. P. Bhatt and J. M. S. Tomar, "Firewood properties of some Indian mountain tree and shrub species," Biomass and Bioenergy, vol. 23, no. 4, pp. 257-260, 2002.

[8] F. Valerio, "Environmental and health impacts of wood combustion to produce heat and power," Epidemiologia e Prevenzione, vol. 36, no. 1, pp. 16-26, 2012.

[9] World Health Organization, Household Air Pollution and Health, 2016.

[10] M. C. Rubio, J. L. Rodríguez Hermosa, and J. L. Álvarez-Sala Walther, "COPD in nonsmokers," Archivos de Bronconeumologia, vol. 46, no. 4, pp. 16-21, 2010.

[11] World Bank Group, Environmental Health Costs in Colombia: The Changes from 2002 to 2010, World Bank Group, 2014.

[12] World Bank Group, Colombia: Strengthening Environmental and Natural Resources Institutions. Study 2: Environmental Health in Colombia: An Economic Assessment of Health Effects, 2012.

[13] DANE, Distribución Poblacional en el Territorio y Relaciones Urbano-Regionales, DANE, Bogotá, Colombia, 2011.

[14] J. Jetter, Y. Zhao, K. R. Smith et al., "Pollutant emissions and energy efficiency under controlled conditions for household biomass cookstoves and implications for metrics useful in setting international test standards," Environmental Science and Technology, vol. 46, no. 19, pp. 10827-10834, 2012.

[15] M. P. Kshirsagar and V. R. Kalamkar, "A comprehensive review on biomass cookstoves and a systematic approach for modern cookstove design," Renewable and Sustainable Energy Reviews, vol. 30, pp. 580-603, 2014.

[16] R. Kataki and D. Konwer, "Fuelwood characteristics of some indigenous woody species of north-east India," Biomass and Bioenergy, vol. 20, no. 1, pp. 17-23, 2001.

[17] M. B. Cardoso, A. H. Ladio, S. M. Dutrus, and M. Lozada, "Preference and calorific value of fuelwood species in rural populations in northwestern Patagonia," Biomass and Bioenergy, vol. 81, pp. 514-520, 2015.

[18] M. A. Ramos, P. M. de Medeiros, A. L. S. de Almeida, A. L. P. Feliciano, and U. P. de Albuquerque, "Can wood quality justify local preferences for firewood in an area of caatinga (dryland) vegetation?" Biomass and Bioenergy, vol. 32, no. 6, pp. 503-509, 2008.

[19] R. Moya and C. Tenorio, "Fuelwood characteristics and its relation with extractives and chemical properties of ten fastgrowth species in Costa Rica," Biomass and Bioenergy, vol. 56, pp. 14-21, 2013.

[20] S. Naik, V. V. Goud, P. K. Rout, K. Jacobson, and A. K. Dalai, "Characterization of Canadian biomass for alternative renewable biofuel," Renewable Energy, vol. 35, no. 8, pp. 1624-1631, 2010.
[21] A. Molino, F. Nanna, and A. Villone, "Characterization of biomasses in the southern Italy regions for their use in thermal processes," Applied Energy, vol. 131, pp. 180-188, 2014.

[22] M.-C. Popescu, C.-M. Popescu, G. Lisa, and Y. Sakata, "Evaluation of morphological and chemical aspects of different wood species by spectroscopy and thermal methods," Journal of Molecular Structure, vol. 988, no. 1-3, pp. 65-72, 2011.

[23] T. D. P. Protásio, L. Bufalino, G. H. D. Tonoli, M. Guimarães Junior, P. F. Trugilho, and L. M. Mendes, "Brazilian lignocellulosic wastes for bioenergy production: characterization and comparison with fossil fuels," BioResources, vol. 8, no. 1, pp. 1166-1185, 2013.

[24] Ministerio de Ambiente y Desarrollo Sostenible, "Lineamientos para un programa nacional de estufas eficientes para cocción con leña," 2014, http://www.si3ea.gov.co/Lena/2014/1A/1_Estufas_Eficientes_Coccion.pdf.

[25] Corpoamazonia, WWF, and Asociación Ampora, Plan de Ordenación y Manejo de la Cuenca Alta del río Putumayo, Corpoamazonia, WWF, and Asociación Ampora, Mocoa, Colombia, 2010.

[26] CORNARE, Criterios Huertos y Estufas Leñeras Limpias, Ambiental y Socialmente Sostenibles-HUELLAS, Antioquia, 2011.

[27] CVS and CMSC, Plan de Gestión Ambiental Regional-PGAR: 2008-2019, CVS and CMSC, Montería, Colombia, 2008.

[28] J. Aristizabal, "Improved cook stoves and fuelwood lots: an alternative of fuel self-supply for small farmers dependent of oak forests in the Colombia eastern cordillera," Colombia Forestal, vol. 2, pp. 245-256, 2010.

[29] G. Shen, W. Lin, Y. Chen, D. Yue, Z. Liu, and C. Yang, "Factors influencing the adoption and sustainable use of clean fuels and cookstoves in China-a Chinese literature review," Renewable and Sustainable Energy Reviews, vol. 51, pp. 741-750, 2015.

[30] D. Medic, M. Darr, A. Shah, B. Potter, and J. Zimmerman, "Effects of torrefaction process parameters on biomass feedstock upgrading," Fuel, vol. 91, no. 1, pp. 147-154, 2012.

[31] J. Cheng, Biomass to Renewable Energy Processes, CRC Press, 2009.

[32] M. Poletto, "Effect of extractive content on the thermal stability of two wood species from Brazil," Maderas. Ciencia y Tecnología, vol. 18, pp. 435-442, 2016.

[33] R. Barrera, J. Perez, and C. Salazar, "Carbones colombianos: clasificación y caracterización termoquímica para aplicaciones energéticas," Ion, vol. 27, no. 2, 2015.

[34] Y. A. Lenis and J. F. Pérez, Estudio del Proceso de Gasificación de Biomasa en Lecho Fijo Equicorriente, University of Antioquia, 2013.

[35] D. Patiño, J. Porteiro, and J. Morán, Análisis experimental de combustión de biomasa en un quemador de lecho fijo [Ph.D. thesis], Universidad de Vigo, 2009.

[36] A. Gupta and D. S. Yan, "Particle size estimation and distributions," in Mineral Processing Design and Operation, chapter 2, pp. 32-62, 2006.

[37] Y. A. Lenis, J. F. Pérez, and A. Melgar, "Fixed bed gasification of Jacaranda Copaia wood: effect of packing factor and oxygen enriched air," Industrial Crops and Products, vol. 84, pp. 166-175, 2016.

[38] R. R. Devi, I. Ali, and T. K. Maji, "Chemical modification of rubber wood with styrene in combination with a crosslinker: effect on dimensional stability and strength property," Bioresource Technology, vol. 88, no. 3, pp. 185-188, 2003. 
[39] ASTM Standard, "Standard test method for rubber property-durometer hardnes," Tech. Rep. ASTM D2240-00, 2010.

[40] Unidad de Planeación Minera Energética (UPME), Integración de las Energías Renovables no Convencionales en Colombia, UPME, Bogotá, Colombia, 2015.

[41] Y. Çengel and M. Boles, Thermodynamics: An Engineering Approach, McGraw-Hill, New York, NY, USA, 8th edition, 2015.

[42] Y.-C. Ko and T.-H. Lin, "Emissions and efficiency of a domestic gas stove burning natural gases with various compositions," Energy Conversion and Management, vol. 44, no. 19, pp. 30013014, 2003.

[43] M. Yunus and A. Saxena, "Performance of LPG cooking stove using different design of burner heads," International Journal of Engineering Research and Technology, vol. 2, no. 7, pp. 656-659, 2013.

[44] Center for Energy Studies, Efficiency Measurement of Biogas, Kerosene and LPG Stoves, Center for Energy Studies, Lalitpur, Nepal, 2001.

[45] W. Barragan, L. Ledesma, and S. Cajas, Sistemas Silvopastorales Para Mejorar la Producción de Leche y Disminuir el Estrés Calórico en la Región Caribe Colombiana, University of Antioquia, 2013.

[46] Cenicafe, "Cenicafe," 2016.

[47] G. O. Mosiori, C. O. Onindo, P. Mugabi, S. B. Tumwebaze, S. Bagabo, and R. B. Johnson, "Characteristics of potential gasifier fuels in selected regions of the Lake Victoria Basin," South African Journal of Science, vol. 111, no. 5-6, pp. 1-6, 2015.

[48] A. A. Tortosa Masiá, B. J. P. Buhre, R. P. Gupta, and T. F. Wall, "Characterising ash of biomass and waste," Fuel Processing Technology, vol. 88, no. 11-12, pp. 1071-1081, 2007.

[49] R. García, C. Pizarro, A. G. Lavín, and J. L. Bueno, "Spanish biofuels heating value estimation. Part I: ultimate analysis data," Fuel, vol. 117, pp. 1130-1138, 2014.

[50] J. F. Pérez, A. Melgar, and A. Horrillo, "Thermodynamic methodology to support the selection of feedstocks for decentralised downdraft gasification power plants," International Journal of Sustainable Energy, pp. 1-19, 2016.

[51] P. Prakash and K. N. Sheeba, "Prediction of pyrolysis and gasification characteristics of different biomass from their physico-chemical properties," Energy Sources, Part A: Recovery, Utilization and Environmental Effects, vol. 38, no. 11, pp. 15301536, 2016.

[52] M. Vaezi, M. Passandideh-Fard, M. Moghiman, and M. Charmchi, "On a methodology for selecting biomass materials for gasification purposes," Fuel Processing Technology, vol. 98, pp. 74-81, 2012.

[53] W. B. Musinguzi, M. A. E. Okure, L. Wang, A. Sebbit, and T. Løvås, "Thermal characterization of Uganda's Acacia hockii, Combretum molle, Eucalyptus grandis and Terminalia glaucescens for gasification," Biomass and Bioenergy, vol. 46, pp. 402408, 2012.

[54] Y. A. Lenis, A. F. Agudelo, and J. F. Pérez, "Analysis of statistical repeatability of a fixed bed downdraft biomass gasification facility," Applied Thermal Engineering, vol. 51, no. 1-2, pp. 10061016, 2013.

[55] A. K. Sharma, "Experimental study on $75 \mathrm{kWth}$ downdraft (biomass) gasifier system," Renewable Energy, vol. 34, no. 7, pp. 1726-1733, 2009.

[56] P. McKendry, "Energy production from biomass (part 2): conversion technologies," Bioresource Technology, vol. 83, no. 1, pp. 47-54, 2002.
[57] I. Janajreh and M. Al Shrah, "Numerical and experimental investigation of downdraft gasification of wood chips," Energy Conversion and Management, vol. 65, pp. 783-792, 2013.

[58] P. Tanger, J. L. Field, C. E. Jahn, M. W. DeFoort, and J. E. Leach, "Biomass for thermochemical conversion: targets and challenges," Frontiers in Plant Science, vol. 4, article 218, 2013.

[59] D. Vamvuka and E. Kakaras, "Ash properties and environmental impact of various biomass and coal fuels and their blends," Fuel Processing Technology, vol. 92, no. 3, pp. 570-581, 2011.

[60] F. Ruiz-Aquino, M. M. González-Peña, J. I. Valdez-Hernández, U. S. Revilla, and A. Romero-Manzanares, "Chemical characterization and fuel properties of wood and bark of two oaks from Oaxaca, Mexico," Industrial Crops and Products, vol. 65, pp. 9095, 2015.

[61] I. Baptista, I. Miranda, T. Quilhó, J. Gominho, and H. Pereira, "Characterisation and fractioning of Tectona grandis bark in view of its valorisation as a biorefinery raw-material," Industrial Crops and Products, vol. 50, pp. 166-175, 2013.

[62] M. Brenes, Biomass and Bioenergy: New Research, Nova Publishers, Hauppauge, NY, USA, 2006.

[63] P. Fu, S. Hu, J. Xiang et al., "FTIR study of pyrolysis products evolving from typical agricultural residues," Journal of Analytical and Applied Pyrolysis, vol. 88, no. 2, pp. 117-123, 2010.

[64] A. Huang, Q. Zhou, J. Liu, B. Fei, and S. Sun, "Distinction of three wood species by Fourier transform infrared spectroscopy and two-dimensional correlation IR spectroscopy," Journal of Molecular Structure, vol. 883-884, no. 1-3, pp. 160-166, 2008.

[65] K. K. Pandey and A. J. Pitman, "FTIR studies of the changes in wood chemistry following decay by brown-rot and white-rot fungi," International Biodeterioration and Biodegradation, vol. 52, no. 3, pp. 151-160, 2003.

[66] K. Qian, A. Kumar, K. Patil et al., "Effects of biomass feedstocks and gasification conditions on the physiochemical properties of char," Energies, vol. 6, no. 8, pp. 3972-3986, 2013.

[67] P. McNamee, L. I. Darvell, J. M. Jones, and A. Williams, “The combustion characteristics of high-heating-rate chars from untreated and torrefied biomass fuels," Biomass and Bioenergy, vol. 82, pp. 63-72, 2015.

[68] E. Mészáros, E. Jakab, G. Várhegyi, P. Szepesváry, and B. Marosvölgyi, "Comparative study of the thermal behavior of wood and bark of young shoots obtained from an energy plantation," Journal of Analytical and Applied Pyrolysis, vol. 72, no. 2, pp. 317-328, 2004.

[69] M. Müller-Hagedorn, H. Bockhorn, L. Krebs, and U. Müller, "A comparative kinetic study on the pyrolysis of three different wood species," Journal of Analytical and Applied Pyrolysis, vol. 68-69, pp. 231-249, 2003.

[70] M. G. Grønli, G. Várhegyi, and C. Di Blasi, “Thermogravimetric analysis and devolatilization kinetics of wood," Industrial and Engineering Chemistry Research, vol. 41, no. 17, pp. 4201-4208, 2002.

[71] C. Frau, F. Ferrara, A. Orsini, and A. Pettinau, "Characterization of several kinds of coal and biomass for pyrolysis and gasification," Fuel, vol. 152, pp. 138-145, 2015.

[72] Z. Chen, M. Hu, X. Zhu et al., "Characteristics and kinetic study on pyrolysis of five lignocellulosic biomass via thermogravimetric analysis," Bioresource Technology, vol. 192, pp. 441-450, 2015.

[73] A. Menéndez and M. D. Curt, "Energy and socio-economic profile of a small rural community in the highlands of central Tanzania: a case study," Energy for Sustainable Development, vol. 17, no. 3, pp. 201-209, 2013. 
[74] D. Smoot, R. Jackson, and J. Smith, "Toward combustion efficiency control criteria in open industrial flares," Hawaii, USA, 2010.

[75] G. Elert, The Physics Hypertextbook, 2016, http://physics.info/ density/.

[76] World Nuclear Association, Heat Values of Various Fuels, 2010. 


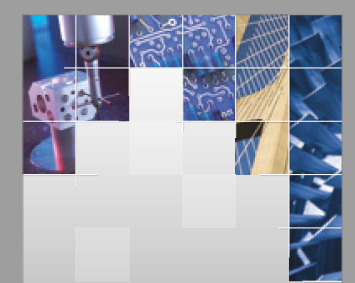

\section{Enfincering}
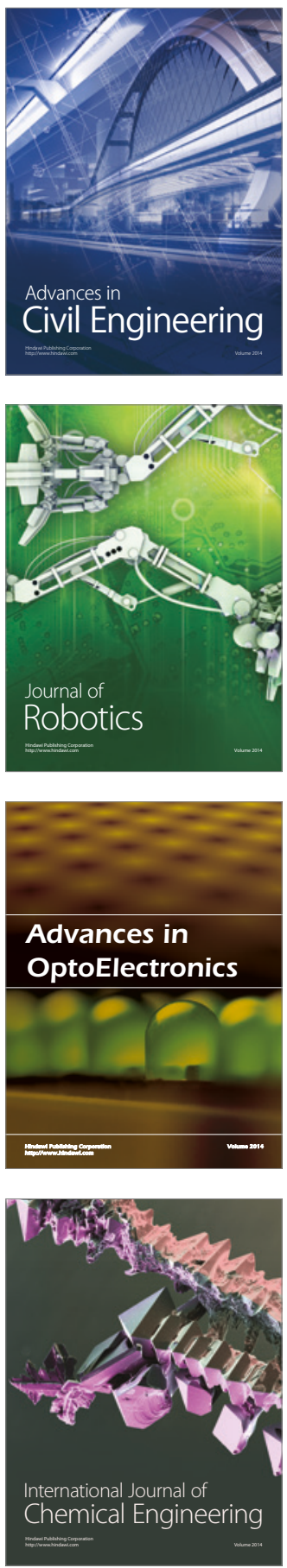

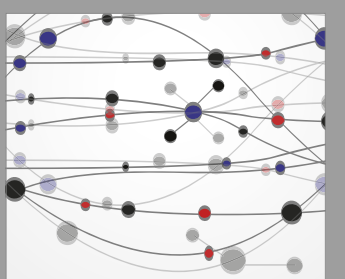

The Scientific World Journal

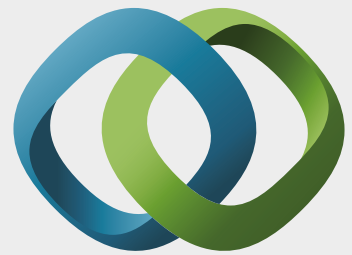

\section{Hindawi}

Submit your manuscripts at

https://www.hindawi.com
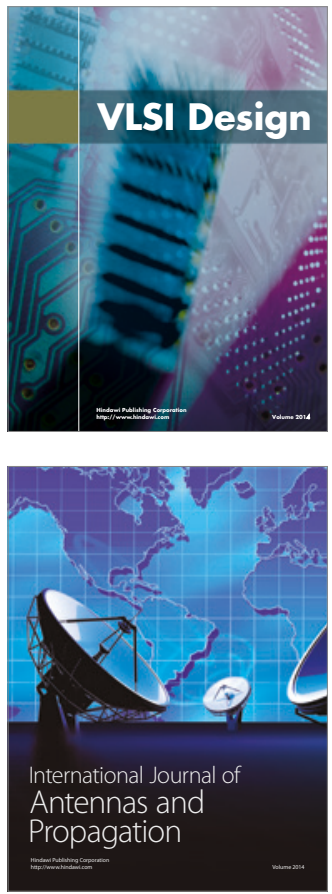

\section{Rotating}

Machinery
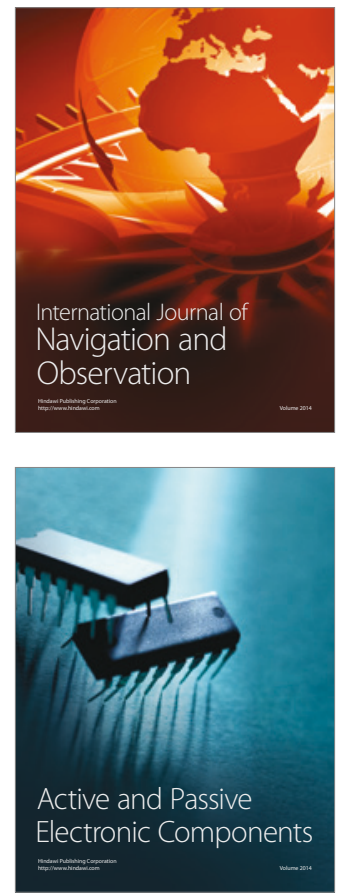
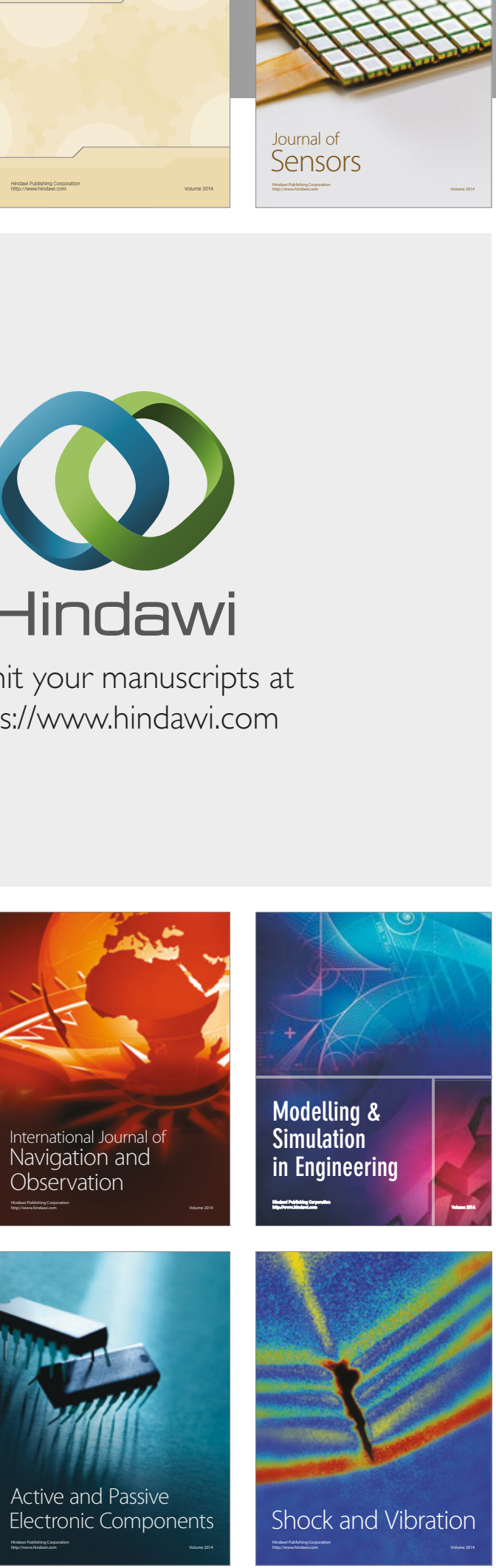
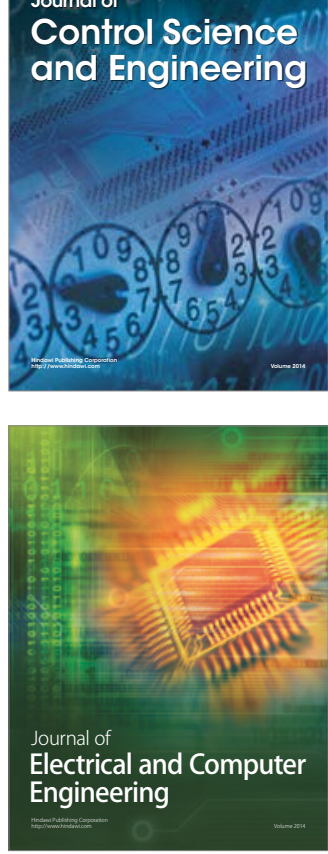

Distributed

Journal of

Control Science

and Engineering
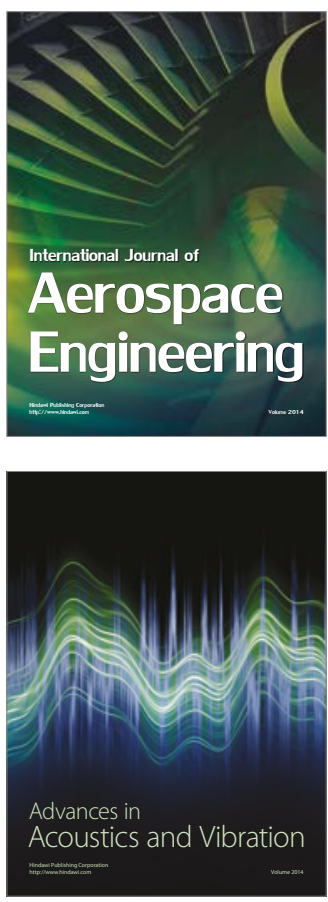

Sensor Networks 